\title{
Study on Innovation Management of Middle-level Manager in Enterprises
}

\author{
Li Zhang ${ }^{1, a}$, Xiaqing $\mathrm{Liu}^{1, \mathrm{~b}^{*}}$ and Mengqing $\mathrm{Ye}^{1, \mathrm{c}}$ \\ ${ }^{1}$ Shandong Technology and Business University, Yantai, Shandong, China 264000 \\ aliuxiaqing111@163.com, b332853225@qq.com, '985660169@qq.com \\ *The corresponding author
}

Keywords: Middle-level manager; Innovation management; Management measure

\begin{abstract}
The middle-level manager is an important link that plays an important and irreplaceable role in enterprise management. The middle manager has the feature of knowledge-type talents and the character of modern enterprise management, which decides that motivations on middle-level managers like pay, bonuses, equity incentive are out-of-date. It is significant to apply a creative and immaterial model like business achievement, personal growth and senses of mission, etc., which provides references and recommendations for innovative thinking and management model of the management of middle-level managers.
\end{abstract}

\section{Introduction}

The internal management of the enterprise is divided into three levels, the top decision-making managing level, the executive management middle-level and the post-operation basic level. Among them, middle-level managers are both executors and leaders. [1] The middle-managers are backbone of enterprises, which takes a special and irreplaceable place in enterprises management. According to a survey from American famous management company McKinsey \& Company, the key factors of many enterprises keeping continuous development are not lie in top-level managers but lie in a group of talented middle-level managers.[2] Middle-level managers are the bridge between top-level decision-makers and inferior executives; The information passed by middle-level managers directly affects the decision-making by enterprises; The attitude and enthusiasm of middle-level managers determines the attitude and enthusiasm of other employees.[3]If middle-level managers play a good role of their posts, then they become a link between top-levels and inferior-levels; If middle-level managers play a bad role of their posts, then they will become a wall standing across top-level and inferior-level. Given the fact, effective management of middle-level managers has become the important strategic component of modern enterprises management, which requires us to form an innovation thinking model and management model.

\section{Limitations of Traditional Middle-level Managers}

Under the changeable and competitive macro environment, many traditional theories and measures are not suitable for managing middle-level managers any more. The worldwide scholars have done a lot of research on it. According to the survey of Clegg and his colleagues, middle managers are often considered by intermediate transitional employees, they are information-transmitters and meanwhile consumers of enterprises resources, so they cannot create values. [4] Yang Weiming found that the management of middle-level managers is out of touch and exerts domino-effects which in the end seriously affect the managing results of enterprises. Because middle-level managers lie in a crevice, they do not be enough understood and paid attention to. [5] Guo Hongbin thought that the traditional motivation is mainly reflected in two aspects: one-sidedness of incentives considers money is the most important and only pays; short-term of incentive process motivates employees by short-term basic pay and bonuses. These traditional incentives may be effective to general employees, however which is not suitable for the middle-level managers. [6] According to survey by Chang Haitao, there are many problems existing between top-levels and middle-levels, mainly "What one says goes", middle-level 
managers have no chance of expressing their own suggestions. Then the top-level managers allocate tasks to middle-level managers without arranging assistants. Or top-levels have a good relationship with middle-levels and top-levels do not investigate the negligence of middle-levels carefully. [7] Liang Luo thought that the main problem of middle-level management is the lack of evaluation system. Lacking of support of theories and basics, there are still no good measures to have a research on how to appoint middle-level managers, how to cultivate middle-level managers, how to promote middle-managers and how to have an appraisal of middle-level managers and need further research. [8]

The writer has done a research on middle-level managers of three state-owned enterprises in Shandong Province, and found three typical problems. Firstly, middle-level managers do not have the right of decision-making and too many responsibilities, so they choose the idea of "Doing nothing and nothing wrong" and "Chinese tumbler". As long as one does nothing, he or she will never make mistakes and never be criticized or even punished. Secondly, middle managers have very few opportunities for promotion while it is probably for middle-level managers to be downgraded depending on the willingness of top-level managers. Therefore, many middle-level managers tend to please top-levels regardless of inferior-levels to assure the safe of their own positions. Thirdly, top-level managers directly interfere with management in inferior department and damage the initiatives and enthusiasm. The middle-level managers are forced to become "polished rod commander" and have nothing to do. Fourthly, as an old saying goes, "People always value opinions coming from sources other than their fellow employees." The top-levels hire external managers with high salaries regardless of what are the existing middle-level managers feeling about. Even though an enterprise develops to a certain scale, they hire a group of middle-level managers from other places to replace most existing experienced middle-level managers in that original old middle-level managers' professional levels are not high, which seriously hurts the self-esteem and damage the enthusiasm of other employees.

\section{The Innovation Management of the Middle-level Managers}

Besides the limitations, the middle-level managers have their own charateristics and advantages. Firstly, as they are in the middle position of the manager hierachy, they can go up or down along the managerial ladder. If a dynamic management mechanism is conducted, the creativity of middle-level managers can be easily motivated. Secondly, the awareness of self-displinary, rules, procedures, and group leadership can improve the sustaible development of an enterprise. Thirdly, it is esay to conduct job rotation among middle-level managers, which can enhance their overall conciseness and sense of consideration. If an enterprise wants to break the limitations of the management of middle-level management, the leader of the enterprise must firstly analyses the features and location of middle-level managers, then make out managing measures according to the modern management theories.

Innovation management refers to the innovation process for management, which includes a series of tools that make managers at all levels cooperate with each other and strive for a common and collective goal. It allows the managers to respond quickly to the external and internal opportunities, and threats and use their creativity to inroduce new concepts, ideas, processes, and products. It is not limited to the field of research and development. Actually, it involves workers and staff at all levels in contributing themselves creatively to a company's long-term planing, development, manuacturing and marketing. The innovatio management for milddle-level managers is crucial to the sustaiable development of an enterprise or an organization.

\section{The Features and Position of Middle-Level Managers}

Liao Shaogang thought that middle-level managers are engaged in activities related to the vertical groups and take on responsibility of their own department. [9] Wanxi thought that the middle managers are the main executives, builders and coordinators. [10] The writer thought that the middle-level managers are concrete executives, adviser, organizer, regulators and servers between top-levels and 
inferior-levels. They often act as department managers, branch factory directors, directors of workshops and section chiefs.

Middle-level managers mostly are graduates and postgraduates from colleges and they are knowledge-typed talents. According to "Modern Chinese Dictionary", knowledge refers to academic, culture and erudition. Knowledge-typed talents are people who have high level of erudition doing mental work. Creativity ability is the main feature of knowledge-typed talents and they are also have features, such as knowledgeable, creative and flexible. Knowledge-typed talents are people with selfishness, public welfare and high social responsibility. The fundamental feature of knowledge-typed talents is that they are rich in knowledge and independent and creative. At the same time, knowledge-typed talents pursue for self-value than other people.

\section{The Innovation Management Measures of Middle-Level Managers}

Middle-level managers are knowledge-typed talents, so regulation measures to them must follow the principle of regulating knowledge-typed talents. Maslow's hierarchy of needs and McClelland's theory of achievement are the theory basics of regulating knowledge-typed talents. The contents of Maslow's hierarchy of needs are physiological needs, safety needs, social interaction needs, esteem needs and self-realization needs. McClelland's theories of achievement are achievement needs, power needs and affinity needs.

According to Maslow's hierarchy of needs, middle-level managers are already satisfied with survival and safety requirements and they need esteem and self-realization, so incentives like money, bonuses, stock-based incentive are not suitable for middle-level managers. According to the research of middle-level managers of Shandong Province, middle-level managers value the business achievement, personal growth and senses of mission.

Business Achievement. Business achievement refers to the desires of success. After accomplishing something successfully, performers will have a feeling of satisfaction, which comes from a sense of achievement. According to McClelland's theories of achievement, middle-level managers are most proud of business achievements. To satisfy the senses of achievement, seniors of enterprises must pay attention to two aspects. For one thing, a developing enterprise is the premise of motivating middle-level managers. If the enterprise develops slowly without excellent business achievements, then middle-level managers are useless and have no enthusiasm. On the contrary, the business of enterprise is thriving and Branch Company and important positions are booming. Then middle-level managers have more chances of taking on more responsibilities and have to manage more people, wealth and things, so the middle-level managers also feel senses of achievement. With the development of enterprise, middle-level managers also are motivated at the same time. For another, full authority is the best way to make middle managers enjoy business success. Giving authority to middle-level managers makes them more power to arrange with their business, giving freedom to let them think independently and make decisions, offer wide space to show their abilities. In this way, they will feel more satisfied with the results when achieving successes. However, the seniors of enterprise management must make sure the middle-level manages who are authorized know their rights are corresponded with their responsibilities. If they do not know the limitations of rights causing wrangles, the order will in chaos, which is harmful to regulation of enterprise.

Personal Growth. Most middle-level managers are in their thirties and forties, during the stages of rise, they have a desire to meet the demand for personal growth. So they have the desire to pay attention to their personal growth. To make middle-level managers grow healthily, three ways must be carries on. Firstly, design the career life for middle-level managers. By designing the career lifetime of middle-level managers, middle-level managers will feel being valued by enterprises. If an enterprise wants to have a good regulation of middle-level managers, it must let the middle-level managers clearly know the career prospects and motivate them by business achievements. Career development motivation is an important measure to motivate middle-level managers. Secondly, pay attention to train middle-level managers. External training and inner training will improve the self-regulated abilities 
and team management abilities. In particular, middle-level managers have already had basic regulatory theories and concepts and needn't have long-period, wide training. In this way, specified classes aimed at companies strategic are suitable for these middle-level managers. At the same time, it is suitable for middle-level managers to apply the model "leadership coaching", hiring leaders who are experienced in regulation as coaches or mentors. Arranging these mentors have a talk with middle-level managers at regular intervals, which is effective than training classes. Thirdly, promote middle-level managers fairly. By public, fair evaluation and rational promotion, excellent middle-level managers will be promoted to higher positions and realize their self-value.

Senses of Mission. Middle-level managers are well graduated and know the great responsibilities. A real enterprise not only has great senses of self-realization, great corporation senses of responsibility and great senses of social missions. An entrepreneur who lacks a sense of mission is not a healthy regulator, which often is ignored by middle-level managers in real life. As a result, seniors of enterprise must remind middle-level managers of correct world view, life view and value view. It is beneficial for middle-level managers to embed this value into the brain. There are two ways to make it. Firstly, by interval regulatory study to make the correct personalities embed in the minds of middle-level managers. Secondly, make middle-level managers stay alert by visiting prison with criminal entrepreneur, avoid "Working hard for decades, one day someone was put into prison for committing crimes". According to survey on more than 20 middle-level managers of an enterprise, middle-level managers are shocked in their minds. After these visits to prisons, criminal affairs obeying business ethics and social morality decrease. Mission management is one of the new kinds of important management method.

Strategic Thinking. The strategic development of an enterprise needs the participation and execution of middle-level managers. Therefore, strategic thinking is an utmost quality for an millde-level manager. Strategic thinking refers to the thinking process of a thinking subject to sovle the overall, long-term and fundamental problems. Strategic thinking strengthment require middle-level managers broden horizon, analyze and diagnoze management situation, and provide valuable information for decision makers of an enterprise. The middle-level managers are also required to balance the relationship between short-term plans and long-term plans, external environment and intenal resource, results and process. It is said that management is a systematic project, and middle-level managers are critical knots of the project. The strateig thinking and systematic thinking of a middle-level managers help them deal with part-whole realtion, and part-part relation effectively, and make final and correct decisions.

Crisis Awareness. Keeping crisis awareness is the prerequisite of impoving innovation ability for middle-level managers. Crisis awareness needs the subjects are prapared for the danger in times of safety, and have high vigilance and sensibility. They are expected to sense the chaning of external and internal environment. Besides, they should pass and communicate messages to their collegues and staff, in order to reduce incorrect ideas of "serving hours" and "muddling along". However, crisis awareness does not mean negative thinking. One should have positive thinking especially facing the challenging and changing. In the case of fierce competition, how to keep entrepreneurial spirit and dialectical thinking is a great test for middle-level managers.

Besides the innovation management, the management model should be formed as well. For example, supervisor management and passive implementation should be transferred to directing-type managemnt and innovation managent.

\section{Summary}

The middle-level manager is an important link that plays an important and irreplaceable role in enterprise management. As early as in 2007, American famous scholar Jon drew a conclusion from "Reform Leaders". If an enterprise wants to develops continuously and achieve high achievements, it must be combined by a group of middle-level managers who are talented at managing business, regulating employees and hard-working at detailed assignments. If senior managers are the brain of 
enterprises, then middle-level managers are the backbone of enterprises. The seniors of regulators should reinforce learning, keep the pace of the development of society, combine the traditional payment, bonuses and stock incentives with business achievement, personal growth and senses of missions, which effectively regulates middle-level managers well and fast keeps the enterprises develop healthily and continuously.

\section{Acknowledgements}

This paper is sponsored by Shandong Social Science Planning Project (No. 14CWXJ49).

\section{References}

[1] Zou Manling. Promoting executive force of middle-level managers, J. Journal of Management, 2010 (10): 43-45.

[2] Xiang Guopeng. Strategic managerial role of middle-level managers of western scholars and its enlightenment, J. Foreign Economy and Management, 2004 (5): 21-25.

[3] Liu Shanshi, Teng Ganggang. Comparative study of managerial ability of middle-level managers in mainland, J. Contemporary Economy Management, 2005 (4): 134-138.

[4] Clegg \& Mcauley. Understanding Human Competence at Work. Academy of Management Journal, 2005, (4): 9-25

[5] Zhang Anmin. Role definition and self-ability improvement of middle-level managers, J. Hubei Agricultural Mechanization, 2008 (3): 13-14.

[6] Guo Hongbin. Consideration on incentive problems of middle-level managers, J. Hunan College of Arts and Sciences, 2006 (4): 118-120.

[7] Cheng Haitao. Motivation on middle-level managers, J. 2007(3): 61-62.

[8] Liang Luo, Xiong Zhiwen. New challenge of management ability of middle-level managers of state-owned enterprise under the new situation. Modern Management and Science, 2011(6): 115-117.

[9] Liao Shaogang, Han Chuanfeng. Comprehensive assessment of management ability of middle-level managers, J. Business Studies, 2008 (1): 25-27.

[10] Wan Xi. Profession Crisis Management of role cognition skills of middle-level managers, J. Economy and Management, 2009 (4): 50-53. 